Article

\title{
What Is Local or Global about Wine? An Attempt to Objectivize a Social Construction
}

\author{
Jean-Marc Touzard *, Yuna Chiffoleau * and Camille Maffezzoli \\ UMR Innovation, Institut National de la Recherche Agronomique (INRA), Montpellier 34060, France; \\ camille.maffezzoli@supagro.inra.fr \\ * Correspondence: touzard@supagro.inra.fr (J.-M.T.); chiffole@supagro.inra.fr (Y.C.); \\ Tel.: +33-499-612465 (J.-M.T.); +33-499-612884 (Y.C.)
}

Academic Editor: Gianluca Brunori

Received: 18 February 2016; Accepted: 19 April 2016; Published: 28 April 2016

\begin{abstract}
What is a "local" food chain as opposed to a "global" chain? Are local food chains more sustainable than global chains? In the context of market globalization and the proliferation of local alternatives, these questions have taken on a new aspect, which has been addressed by the GLAMUR (Global and Local food chain Assessment: a Multidimensional performance-based approach) project. Using an analysis of three archetypal wine chains in the south of France, and considering food chains as embedded social constructions, we will first attempt to objectivize which aspects of wine are local, and which are global, using a multidimensional analytical approach. As local vs. global characteristics seem to be strategic assets or constraints, and not structural components, we will then outline an evaluative approach to wine chain sustainability by valuing qualitative indicators to be scored and benchmarked by experts. We will discuss our findings from a scientific and operational perspective by highlighting how a local vs. global approach produces new sustainability issues and practical solutions. Nevertheless, as concrete chains often mix global and local characteristics, further research must be done in order to assess how this combination may be sustainable for different types of actors, depending on their values, capacities, networks and constraints.
\end{abstract}

Keywords: local food value chain; global food value chain; wine; sustainability assessment; economic sociology; new indicators of wealth; Languedoc

\section{Introduction}

The distinction between "local" and "global" has emerged as a hot topic of debate in food sectors, in relation to the challenges of sustainability. "Local food," "local food systems" and "local food chains" have been promoted by social movements that criticize the globalization of food [1-3]. The notion of "localness" has now been appropriated by new entrants, including global players such as supermarkets and policy makers [4]. As it is drawn into a wider social arena, the distinction between "what is global" and "what is local" has become less and less obvious, reflecting the complexity of the concrete food economy and the diversity of judgments among its actors [5]. The GLAMUR European FP7 research project was launched in order to clarify this issue and to propose assessment tools for local vs. global food chains. The objective of this article is to address this local vs. global issue in the case of the wine industry through the multidisciplinary approach that was adopted in the GLAMUR project. The GLAMUR project evaluated 39 cases of local, intermediate or global supply chains across different commodities and countries, including the wine chains presented in this article. Covering environmental, economic, social, health and ethical sustainability dimensions, GLAMUR highlighted the need to complete "hard" methodologies, such as Life Cycle Analysis, through "soft" methodologies which are often more able to identify critical issues, trade-offs and best practices (For details on the GLAMUR approach, see Brunori et al. in this special issue of Sustainability.). In this 
article we combined the GLAMUR approach with an economic sociology theoretical framework. We will argue that the attempt to objectivize the local and global dimensions of wine chains cannot be achieved by a descriptive and analytical approach, and must therefore be complemented by a more interpretative and evaluative approach to embedded food systems.

The wine industry can be seen as an archetypical example of a case where many dimensions of both local and global contexts are combined, institutionalized, and debated. Since Antiquity, wine has been an essential component of the domestic consumption of local communities in the Mediterranean area, and, at the same time, a key commodity in long-distance trade [6]. From early on, the local and global dimensions of wine were linked with quality [7]: while basic wine was locally drunk and exported all over Europe to "nourish" soldiers and workers (from Roman soldiers to the workers of the industrialization period), prestigious wines ("fine wines") were sought and distinguished according to their place of origin (or terroirs) by the aristocracy, the bourgeoisie and the new upper class [8]. In a broader context, scientific literature has identified at least five aspects of the local vs. global issue that have played a role in the evolution of the wine industry:

(i) The geographical distance between the production and the consumption of wine was the focus of intense debate among French geographers in the early 20th century, specifically regarding the issue of how vineyard location was influenced by suitable local natural conditions or by geographical distance from cities, consumers or harbors $[9,10]$. Local/domestic wines and exported/global wines were thus distinguished from each other early on, demonstrating how different chains resulted in diverse, more or less specialized, kinds of vineyards [11,12]. Research into the spatial determination of vineyards and wine markets has been relaunched in recent years, exploring, for example, the new geography of wine tourism $[13,14]$.

(ii) The literature has also focused on relational proximity, contrasting face-to-face relations between wine producers and consumers with the impersonal purchase of wine in a supermarket [15]. A global wine appears as an "anonymous" wine in such an approach, while a local wine references interpersonal relations [16], "cognitive proximity" [17] and reflexive activity between producers and consumers [18]. The number of intermediaries along the chain could thus be an indicator of relational proximity, and labels such as trademarks or official quality marks can be justified by the need for trust in global wine markets, to offset the lack of personal ties [19].

(iii) Further, as wine quality is very sensitive to local conditions such as soil and climate, local/specific resources are thought of and discussed as a key criterion of wine quality, as opposed to global/substitutable resources such as international vine varieties and wine-making technologies [20]. The nature of the resources which are integrated in the production processes, including knowledge, can thus help to distinguish what is local or global about wines for both the local and the global market. Many scholars have analyzed the local determinism of quality in an attempt to objectivize the terroir [21,22], a notion proceeding from the history of wine production. Terroir refers not only to "natural" local resources and agronomic practices, but also to local knowledge, culture and history $[23,24]$.

(iv) The way supply chain actors shape and promote the wine identity with regard to the area of production (whether it is called terroir or not) has been the object of a great deal of research in geography, economics and sociology, above and beyond the incorporation of local resources into production $[7,25,26]$. Some of these studies focus on how final consumers recognize-and will pay for-local vs. global attributes of wine quality, such as geographical name, image, narrative or intrinsic characteristics [27]. Other research shows the complex process of wine qualification involving technical, economic and social interactions between many actors along the chain, and not only marketing strategies responding to consumers' preferences [28]. Wine is an archetypical example of a market where origin plays a significant role, and where Geographical Indications are used to protect "local identity" and other public goods in the global market [20].

(v) The local vs. global nature of wine chains also results from "who controls the chain," i.e., local or global governance. Wine producers and their local organizations (associations, cooperatives, or 
trade unions) play an important role in the wine industry, particularly by controlling Geographical Indications or promoting wine routes [12]. Nevertheless, big companies, international investors, wholesalers and supermarkets have strengthened their market power in many countries, and have come into competition or conflict with wine producers [29]. The opposition between local and global governance has been studied for many wines, including Champagne, Porto, Western Cape and Mendoza [30-33].

Five aspects of local vs. global have therefore been studied in the wine industry: the geographical distance between consumption and production, the number of intermediaries, the nature of incorporated resources, the product identity built along the chain, and the level of governance. What, however, is local or global about wine in the end? Can we develop a composite view based on the combination of these five analytical aspects? Following the GLAMUR approach, we will suggest that the clarification and the objectivization of this question cannot simply rely on a descriptive analysis of these "structural" aspects of wine chains. We need to move to a consequentialist approach, and assess how the local and global dimensions of wine chains are considered in regards to their impact on sustainability.

In the second section of the paper, we will present our method for describing and assessing three different types of wine chains: "local," "global" and "local in global." These chains start in the Languedoc wine region in the south of France and have been evaluated in regards to six main attributes of sustainability. In the third section, we will report the main results of (i) the description of the three wine chains, and (ii) their multidimensional assessment in terms of the six attributes. In the fourth section we will discuss these results and demonstrate that the move to a consequentialist approach provides new insights into what is global or local about wine, and also calls for another approach in which "global" and "local" wines are considered as co-evolving social constructions, embedded in values, networks and institutions [34].

\section{Materials and Methods}

\subsection{Step One: Selection of Case Study and Analytical Approach to Local vs. Global Chains}

The wine industry seems to us archetypical, and thus an ideal case study for exploring more deeply the local vs. global issue as we began to do in previous research, both in terms of description and assessment. We propose to develop the approach we used on the Languedoc vineyard, where a wide range of wine qualities and chains co-exist, from basic wine sold in bulk for the national market, to the finest bottled wines purchased locally and exported all around the world [28]. Our team has been researching this vineyard for twenty years, using a multidisciplinary approach that has focused on innovation processes [35]. The GLAMUR project has provided an opportunity to highlight and develop previous results as well as diverse scientific and professional partnerships.

For the first step, using an analytical approach, we have applied the five key aspects highlighted above, which were used in the GLAMUR project to differentiate local vs. global chains, and to understand how "global" and "local" are manifested in the case of Languedoc wines. Both primary and secondary data have been used to describe "global" and "local": interviews with 12 key respondents from institutional, economic, political and public spheres concerned in the Languedoc wine industry on the one hand, a review of articles, reports, websites, and regional statistics on the other. The Table 1 presents how "local" vs. "global" chains are the most frequently described for each aspect, according to all these sources of data.

This grid theoretically allows multiple combinations between parameter values in each of the five key dimensions. The case of Languedoc wine illustrates many different combinations, but three main archetypes of wine chains in this vineyard are highlighted by experts and in the literature on the subject: case A combines the characteristics associated with local chains in each dimension; case B gathers all the characteristics of global chains, and $C$ is an intermediary case that is linked with both 
local resources and Protected Denomination of Origin (PDO) wines, and oriented towards the export market (see Figure 1).

Table 1. Description of local and global characteristics in wine value chains along five key dimensions of differentiation, applied to Languedoc wine chains.

\begin{tabular}{|c|c|c|}
\hline Key Dimensions & Definition & Parameter(s) \\
\hline \multirow[t]{2}{*}{ Number of chain operators } & \multirow{2}{*}{$\begin{array}{l}\text { Number of actors involved in } \\
\text { the food supply chain between } \\
\text { producers and consumers }\end{array}$} & Local: Between 0 and 1 (a) \\
\hline & & Global: More than $1(b)$ \\
\hline \multirow{2}{*}{ Scope of the chain } & \multirow{2}{*}{$\begin{array}{l}\text { Geographical scale of the chain, } \\
\text { between production and } \\
\text { distribution areas }\end{array}$} & $\begin{array}{l}\text { Local: production and distribution on regional } \\
\text { scale. Direct sale at cellar (c) }\end{array}$ \\
\hline & & $\begin{array}{l}\text { Global: production and distribution on } \\
\text { national, European and international scales (d) }\end{array}$ \\
\hline \multirow{2}{*}{ Resources used in the chain } & \multirow{2}{*}{$\begin{array}{l}\text { Origin of resources mobilized by } \\
\text { chain actors for wine processes }\end{array}$} & $\begin{array}{l}\text { Local: Main input (goods and services) } \\
\text { coming from local and regional markets (e) }\end{array}$ \\
\hline & & $\begin{array}{l}\text { Global: Main input from national and } \\
\text { international markets (f) }\end{array}$ \\
\hline Governance of the chain & $\begin{array}{l}\text { Types of actors involved in } \\
\text { decision-making processes and } \\
\text { in management of flows within } \\
\text { the chain }\end{array}$ & $\begin{array}{l}\text { Local: Chain driven by producers }(\mathrm{g}) \\
\text { Global: } \\
\text { - Chain driven by traders and distributors with } \\
\text { wine cooperatives for production (h) } \\
\text { - Chains co-driven by producers and traders (i) }\end{array}$ \\
\hline \multirow{2}{*}{$\begin{array}{l}\text { Product identity and } \\
\text { marketing strategy }\end{array}$} & \multirow{2}{*}{$\begin{array}{l}\text { Category of wine quality and } \\
\text { quality attributes used for } \\
\text { marketing strategy }\end{array}$} & $\begin{array}{l}\text { Local: Product with references to the Terroir, } \\
\text { Protected Denomination of Origin (PDO) } \\
\text { and/or Organic Label (j) }\end{array}$ \\
\hline & & $\begin{array}{l}\text { Global: Geographical indication (PGI), Trader } \\
\text { or Distributor Brand }(\mathrm{k})\end{array}$ \\
\hline
\end{tabular}

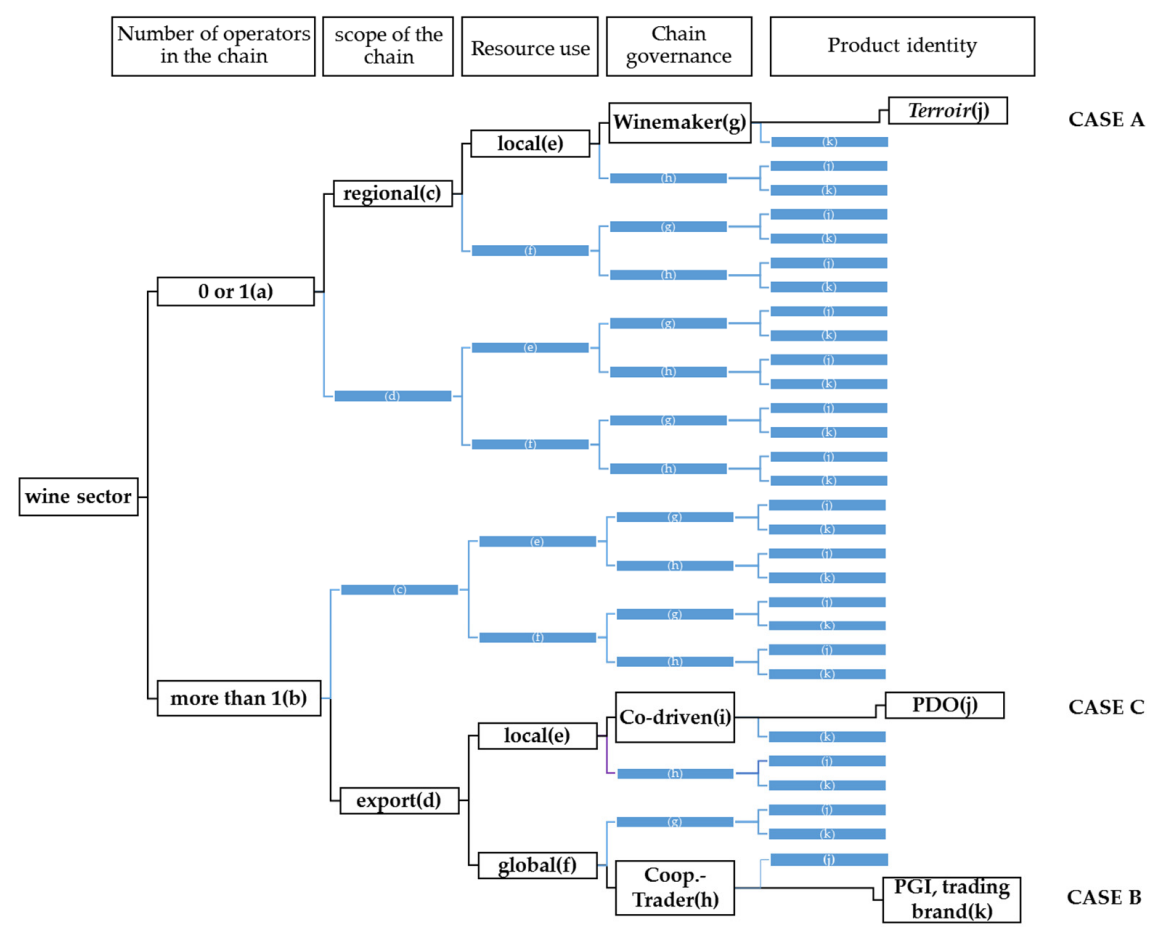

Figure 1. Analytic approach to wine chain diversity in Languedoc and position of the three most common chains, in terms of differentiating dimensions. 
The three cases have been fully described using diverse sources of data and with the help of the Global Value Chain approach [36] in order to delve deeper into the governance dimension. From three variables (complexity of transactions, codification of information, competences of suppliers), Gereffi identified five types of governance patterns in cross-border economic activities; the GVC approach is a way of going beyond market $v$ s. hierarchy governance models by exploring modular, relational and captive governance through networks. This step already highlighted some issues regarding the performance of these three cases which we went on to develop in step two.

\subsection{Step Two: Interpretative Approach to Local vs. Global Chains through Their Performance}

In step two, we adapted the frame of the GLAMUR project in order to assess, with stakeholders, how local vs. global chains may be defined, not per se, but through what they produce, induce, limit or destroy, in the different domains of sustainability.

We combined a participatory approach with our own expertise, through an iterative process between field perspective and the objectivization process. The first task was to define the main issues concerning Languedoc wine chain performances, as highlighted by experts and in the literature utilized in the first step. We therefore selected the attributes that are most relevant to wine chains from the list of the 24 performance attributes defined in the GLAMUR project frame. In this paper, we have focused on six of the performance of local vs. global chain attributes (see Table 2), from the original eight which appeared significant in the case of Languedoc wine.

Table 2. List and definition of attributes of chain performances selected in wine chains example.

\begin{tabular}{|c|c|}
\hline Attribute & Definition \\
\hline $\begin{array}{l}\text { Creation and distribution } \\
\text { of added value }\end{array}$ & $\begin{array}{l}\text { How value is created, and how it is distributed within the food chain. } \\
\text { Issue linked with the notion of fairness and equity. }\end{array}$ \\
\hline Connection & $\begin{array}{l}\text { "Connection" refers to the notion of cooperation and to relationships between } \\
\text { actors involved in the chain and with consumers. This attribute covers social } \\
\text { links, inter-firm relations and strategic relations with the policy sphere. }\end{array}$ \\
\hline Resource Use & $\begin{array}{l}\text { Resource use is an overarching attribute since it concerns the use and } \\
\text { management of the flows of available resources through food chains } \\
\text { (land, energy, other materials). }\end{array}$ \\
\hline Biodiversity & $\begin{array}{l}\text { Food production effects on biodiversity at different levels, corresponding to } \\
\text { the ability of food supply chains (i) to preserve the stock of biodiversity; (ii) to } \\
\text { develop animal and plant diversity. }\end{array}$ \\
\hline Food Safety & Prevention and control processes for food hazards and contamination. \\
\hline Territoriality & $\begin{array}{l}\text { The capability of the chain to represent and promote (i) its links with a } \\
\text { specific production place and (ii) the localness of a product. }\end{array}$ \\
\hline
\end{tabular}

The following task involved identifying a relevant set of indicators to assess chain performances regarding these six attributes. We started with the SAFA tool (Sustainability Assessment of Food and Agriculture systems) proposed by the Food and Agriculture Organization of the United Nations (FAO) [37]. However, SAFA indicators are often complex or too general to be easily assessed, and thus call for a proxy or have to be detailed in several sub-indicators. More broadly, our assessment approach relied on the contribution of economic sociology to the analysis of economic activities: these activities are considered as "embedded" in social structures, which influence their forms and their results [38]. This approach is a way of assessing concrete markets and taking into account the "context" of their operation and dynamics. One part of economic sociology, anchored in the English-speaking world, focuses on the role of social networks [39]; another, more developed in the French-speaking world, addresses the role of institutions and cognitive factors as social components of the context [40]. In our research, we have tried to combine these two traditions, whereby the synthesis is often limited by the difficulty of assessing the concrete relational dimension of markets in detail: in particular, 
while a lot of research emphasizes the "social link" in local food chains [41], our objective here has been to consider the relational dimension by paying greater attention to their nature in different food chain contexts. Moreover, from the perspective of economic sociology, where social contexts such as networks and institutions influence forms and results of economic activities, new evaluation indicators of economic actions and markets, whether they be quantitative or qualitative, are considered as relevant for specific actors in specific contexts: This approach has been broadly developed, beyond classical and mainstream economic quantitative data, through research into "new indicators of wealth," such as cash-flow positions, wellbeing and change of practice [42].

Using a focus group of experts, including representatives from market, public and scientific spheres, each attribute has been sub-divided into several indicators, which have themselves been divided into different sub-indicators. Qualitative sub-indicator scores have been based on the level or the number of good practices implemented by actors in each domain concerned, and/or on the presence or absence of factors which the group of experts believes influence performance in this domain. Each piece of data or score has been compared against a benchmark to facilitate converting the assessment on a performance level: for quantitative data, reference values have been set based either on regional or national wine sector statistics, including the average turnover at the farm level, or on legal thresholds, for instance, regarding health and food safety. For qualitative indicators, benchmarks have been defined by the set of good practices and/or factors needed to achieve the "best" performance in a specific domain. Benchmarking has been the most controversial task in our research, provoking some disagreements between experts concerning the best data or practices for a specific domain, and because performance domains are not independent of each other. Nevertheless, after some deliberation, we reached a consensus on most of the 20 indicators selected to cover the case of wine.

In this paper, we have presented the subdivision of nine of the 20 indicators which were used to assess the wine case studies: these nine indicators (see Table 3) cover the economic, social, environmental and ethical dimensions of sustainability (see Appendix). They are useful for addressing local vs. global chain characteristics and illustrating our socioeconomic approach. Data has been collected through in-depth interviews with 24 actors in the Languedoc wine industry, which were conducted as part of earlier research covering overlapping issues [43]; they have been augmented by 2014 GLAMUR-focused interviews with six wine producers, two cooperative managers and two retailers chosen as characteristic of the three archetypal food chains; moreover, they have been discussed and validated by a focus group of experts drawn from scientists and experts from professional organizations.

Table 3. Description of indicators selected in the Languedoc wine study case.

\begin{tabular}{clc}
\hline Attribute/Indicator & \multicolumn{1}{c}{ Description } & Unit \\
\hline $\begin{array}{c}\text { Farmer revenue } \\
\text { before taxes }\end{array}$ & $\begin{array}{l}\text { Revenue before taxes per farmer in wine production per } \\
\text { non-salaried worker. Quantitative. }\end{array}$ & $\begin{array}{c}\text { Euro per Annual Work } \\
\text { Unit, } € / \text { AWU }\end{array}$ \\
\hline $\begin{array}{c}\text { Distribution of added } \\
\text { value along the chain }\end{array}$ & $\begin{array}{l}\text { Breakdown of consumer price of bottle in costs, taxes } \\
\text { and commercial margins. Quantitative. }\end{array}$ & $\begin{array}{c}\text { Percentage of the selling } \\
\text { price, } \%\end{array}$ \\
\hline $\begin{array}{c}\text { Contribution to } \\
\text { employment }\end{array}$ & $\begin{array}{l}\text { Total number of hours worked, at farm level, for wine } \\
\text { production and selling. Quantitative. }\end{array}$ & $\begin{array}{c}\text { Full-Time Equivalent } \\
\text { per unit of land, FTE/ha }\end{array}$ \\
\hline & \multicolumn{1}{c}{ Connection } & Score the \\
Farmer cooperation & $\begin{array}{l}\text { Practices and forms of cooperation between wine } \\
\text { producers. Qualitative. Two sub-indicators: Active } \\
\text { participation in farmers' networks; Existence of mutual } \\
\text { support among farmers. }\end{array}$ & $\begin{array}{c}\text { implementation of } \\
\text { practices (points) }\end{array}$ \\
\hline
\end{tabular}


Table 3. Cont.

\begin{tabular}{|c|c|c|}
\hline Attribute/Indicator & Description & Unit \\
\hline \multicolumn{3}{|c|}{ Biodiversity } \\
\hline $\begin{array}{l}\text { Species conservation } \\
\text { practices }\end{array}$ & $\begin{array}{l}\text { Practices and criteria related to management of } \\
\text { biodiversity at farm level. Qualitative. } \\
\text { Three sub-indicators: Diversity of vine varieties at farm } \\
\text { level; Uncultivated biodiversity (landscape, flora and } \\
\text { fauna protection); Integration of agro-ecological } \\
\text { practices for pest control. }\end{array}$ & $\begin{array}{l}\text { Score the } \\
\text { implementation of } \\
\text { practices (points) }\end{array}$ \\
\hline \multicolumn{3}{|c|}{ Resource use } \\
\hline Water-Use Practices & $\begin{array}{l}\text { Practices and criteria related to water use at vineyard } \\
\text { management level. Qualitative. Three sub-indicators: } \\
\text { Irrigation strategy for grape production; Technology and } \\
\text { equipment used for irrigation; Water } \\
\text { preservation practices. }\end{array}$ & $\begin{array}{l}\text { Score the } \\
\text { implementation of } \\
\text { practices (points) }\end{array}$ \\
\hline \multicolumn{3}{|c|}{ Food safety } \\
\hline $\begin{array}{l}\text { Food Safety Standards } \\
\text { and controls }\end{array}$ & $\begin{array}{l}\text { Practices and criteria linked with management of food } \\
\text { security at the level of the chain. Qualitative. } \\
\text { Three sub-indicators: Direct relation between producer } \\
\text { and consumer; Control and monitoring by third-party } \\
\text { organisms; Implementation of management system } \\
\text { along the chain. }\end{array}$ & $\begin{array}{l}\text { Score the } \\
\text { implementation of } \\
\text { practices (points) }\end{array}$ \\
\hline \multicolumn{3}{|c|}{ Territoriality } \\
\hline $\begin{array}{l}\text { Association of product } \\
\text { with territory }\end{array}$ & $\begin{array}{l}\text { Practices and criteria contributing to maintaining the } \\
\text { economic and environmental dynamics and specificities } \\
\text { of wine production areas. Qualitative. } \\
\text { Four sub-indicators: Enhancing landscape and terroir; } \\
\text { Contribution to territorial economic development } \\
\text { (percentage of commercial margin remaining on the } \\
\text { territory); Average number of full-time jobs at farm level; } \\
\text { Use of knowledge and know-how valuing the terroir. }\end{array}$ & $\begin{array}{l}\text { Score the } \\
\text { implementation of } \\
\text { practices (points) }\end{array}$ \\
\hline $\begin{array}{l}\text { Social cohesion and } \\
\text { Conviviality }\end{array}$ & $\begin{array}{l}\text { Practices and criteria contributing to maintaining social } \\
\text { and ethical dynamics in wine production areas. } \\
\text { Qualitative. One sub-indicator: Participation of wine } \\
\text { actors to territorial initiatives/events. }\end{array}$ & $\begin{array}{l}\text { Score the } \\
\text { implementation of } \\
\text { practices (points) }\end{array}$ \\
\hline
\end{tabular}

\section{Results}

\subsection{Results from Analytical Approach to Local and Global Chains}

Our practical knowledge of the wine sector, along with interviews with experts and a literature review, have resulted in drawing attention to three examples of wine chains in the Languedoc-Roussillon region which demonstrate extreme positions in "local" (Case A), and "global" (Case B) chains, and one intermediary case (Case C), involving both local and global characteristics. For each case, we will describe the supply chain range and governance, and focus on physical market, financial and information flows from wine producers to their providers and to consumers of bottled red wine. Regarding governance patterns, we will highlight the complexity of transactions, codification of information and competence of suppliers.

Case A reflects all the characteristics of the "localness'" of the Languedoc wine industry (see Table 1). The "domain" (wine estate) mainly relies on family labor, which controls all the processes from production to sale, and is augmented by seasonal and permanent employees. Vines must mostly be bought from a regional nursery, as authorization for own-breeding is restricted in France, but traditional varieties (Carignan, Mouvèdre, Cinsault, etc.) are valued in wine making. Wine quality is determined by specific local conditions including soil, grape variety, canopy management and family know-how, and is also correlated to low yields that fluctuate around 30 hectoliters per hectare. The 
main tendency in this chain is to follow labelling criteria (PDO and/or organic), without systematically mentioning this on the bottle: information is directly exchanged between the producers and their clients. Grape production requires a skilled labor force, particularly during the harvest which is mainly picked by hand. High relational investments with clients aim at strengthening the wine's reputation and visibility in local and regional markets, to both local consumers and tourists, and to restaurants and wine merchants (see Figure 2). Relational investments also focus on other local actors in tourism, landscaping, fairs and cultural events. With complex transactions based on mutual dependence, trust, social and spatial proximity and low codification of information in formal devices, this chain, which requires a high level of competence from suppliers, relies on a relational governance pattern [36] which is time-consuming and difficult to scale up.

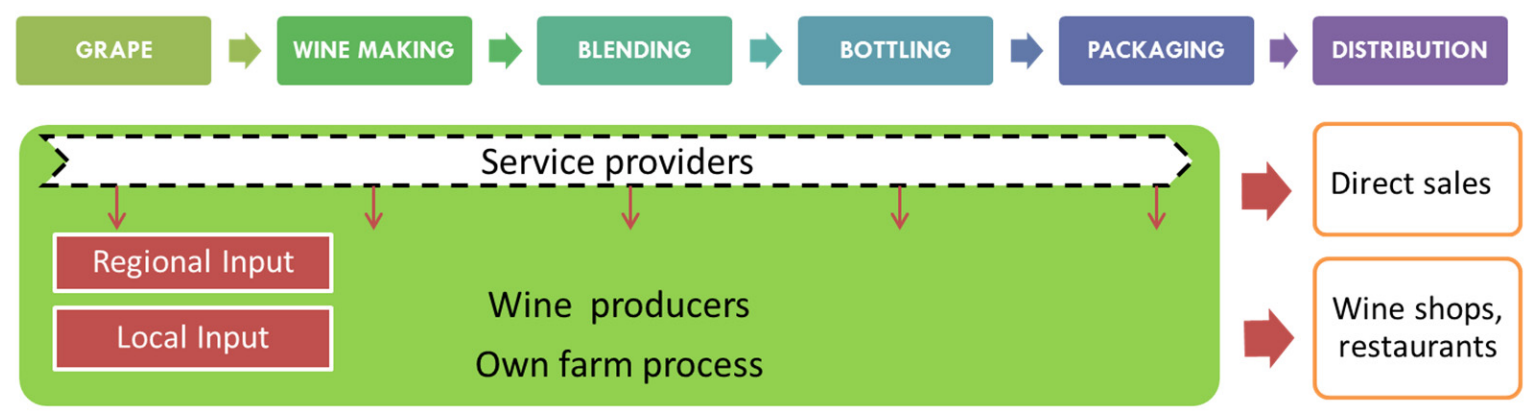

Figure 2. Archetype of local wine supply chain.

Case B is a bulk wine supply chain oriented towards export strategies. The final product fulfils the standardized criteria established by the trade-brand owner. The wine brand is combined with a Protected Geographical Indication (PGI) label such as PGI "Pays d'Oc" and the wine is made from the most commonly cultivated vine varieties in the world (Merlot, Syrah, Cabernet-Sauvignon). In accordance with the international trend towards the New World, varieties are often named on the bottle. Operations from grape production to first bulk sale of wine are managed by grape-growers and their big cooperatives. These actors implement "cost-volume" strategies. Vineyards are mainly located on plains and are managed according to an intensive production model which produces yields of between 80 to 110 hectoliters per hectare (hL/ha). Different strategies are implemented by wine cooperatives in order to be competitive on the global market: (1) investment in production (irrigation systems, restructuring of vine plots to facilitate mechanization and reduce costs); (2) merging and concentration of wine-making units, reducing costs and increasing negotiation power with traders; (3) specialization in one main market strategy (white or red varieties, spot or contractual markets). The bulk wine market is driven by a handful of international companies which purchase large quantities of wine from cooperatives or regional traders (see Figure 3). These big companies manage the bulk logistics, blending, bottling and marketing of bottled wine in supermarkets. These technical operations follow an industrialized process which is located far from the production area and needs a large storage capacity. As regards governance, with little explicit coordination of transactions, and with easily codified information, the global bulk chain, requiring as it does little cognitive input from suppliers, demonstrates the market governance model [36]. 


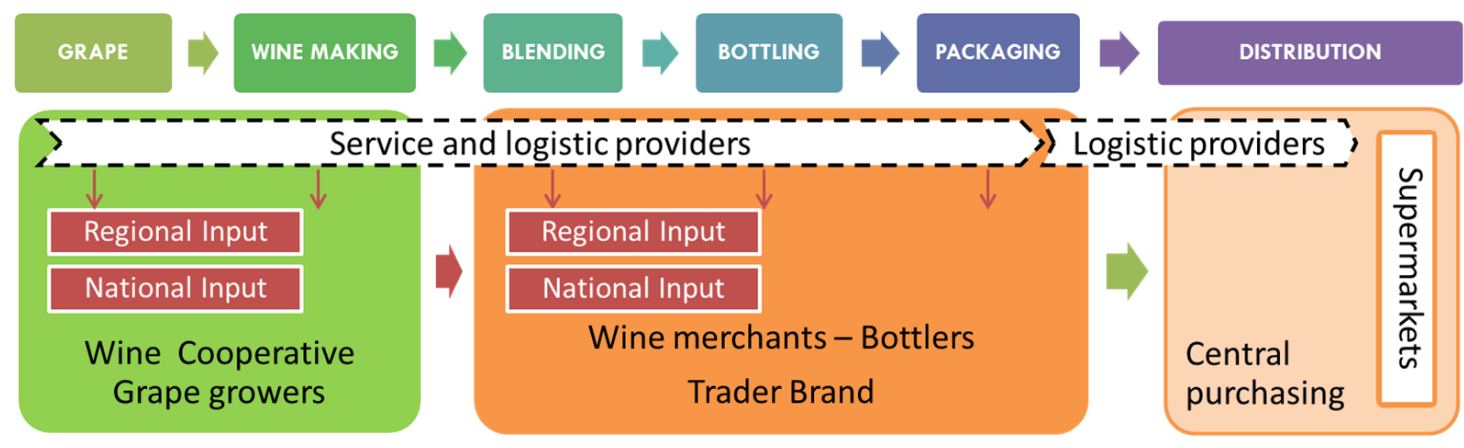

Figure 3. Archetype of global bulk wine supply chain.

Case C starts with grape and wine production in domains or small cooperatives located on Languedoc hillsides. Wine production relies on local resource management in order to fulfil practices associated with PDO specifications or organic agriculture. Wine is bottled in the PDO area and sold in the global market to specialized wholesalers, mainly importers, who promote differentiated wines whose quality attributes are tied to both the terroir and, increasingly, to organic practices. The final consumer is assumed to be a connoisseur. These global chains promote quality and a local image in wines. They require strong support from wine producer organizations and regional institutions, and they coordinate actor strategies for entering the market (finding clients, negotiating contracts, organizing logistics in international markets) and for building a specific identity for Languedoc wines in order to raise international client awareness. Transactions between producers and consumers are thus complex, but are facilitated by the codification of information via the label, thus requiring suppliers to have specific knowledge in order to fulfil the guidelines associated with the label; in this way, this chain is an example of a modular governance model (see Figure 4).

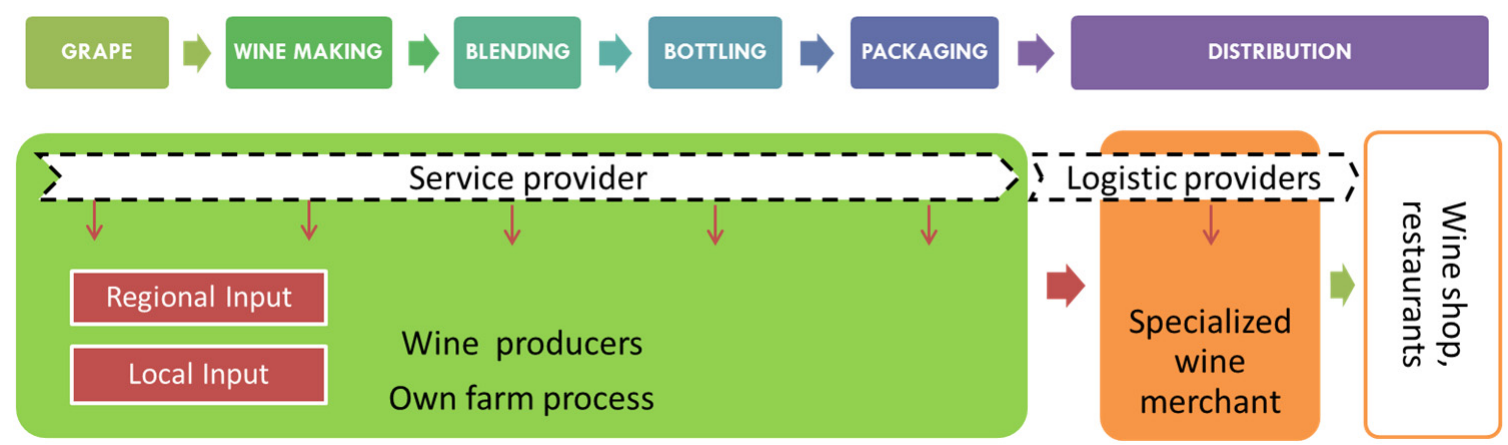

Figure 4. Archetype of global bottled wine supply chain.

\subsection{Results from Interpretative Approach to Chain Performances, by Attribute and Indicator}

In this section, we develop results and performances levels for each attribute, and compare the three cases of chains. Results and the performance level for each indicator in each chain are summarized in Table 4. More details are provided in Appendix. 
Table 4. Results and performance level for each indicator.

\begin{tabular}{|c|c|c|c|c|c|c|}
\hline \multirow{2}{*}{ Indicator } & \multicolumn{2}{|c|}{ Case A: Local Chain } & \multicolumn{2}{|c|}{ Case B: Global Bulk Chain } & \multicolumn{2}{|c|}{ Case C: Global Bottled Chain } \\
\hline & $\begin{array}{c}\text { Value } \\
\text { (Unit/Score) }\end{array}$ & $\begin{array}{l}\text { Performance } \\
\text { Level }(\%)\end{array}$ & Value (Unit/Score) & $\begin{array}{l}\text { Performance } \\
\text { Level (\%) }\end{array}$ & Value (Unit/Score) & $\begin{array}{c}\text { Performance } \\
\text { Level (\%) }\end{array}$ \\
\hline $\begin{array}{l}\text { Farmer revenue before taxes } \\
\qquad(€ / A W U)\end{array}$ & 15,000 to 18,000 & $42 \%$ to $50 \%$ & 20,000 to 24,000 & $56 \%$ to $67 \%$ & 15,000 to 20,000 & $42 \%$ to $56 \%$ \\
\hline $\begin{array}{l}\text { Contribution to employment } \\
\text { (FTE/ha) }\end{array}$ & 0.17 & $85 \%$ & 0.10 & $50 \%$ & 0.13 & $65 \%$ \\
\hline Farmer cooperation (Score) & $6 / 8$ & $75 \%$ & $5 / 8$ & $63 \%$ & $5 / 8$ & $63 \%$ \\
\hline Species conservation (Score) & $7 / 7$ & $100 \%$ & $4 / 7$ & $57 \%$ & $7 / 7$ & $100 \%$ \\
\hline Water-Use Practices (Score) & $7 / 8$ & $88 \%$ & $3 / 8$ & $38 \%$ & $5 / 8$ & $63 \%$ \\
\hline $\begin{array}{c}\text { Food Safety Standard and } \\
\text { control (Score) }\end{array}$ & $2 / 5$ & $40 \%$ & $3 / 5$ & $60 \%$ & $4 / 5$ & $80 \%$ \\
\hline $\begin{array}{l}\text { Association with territory } \\
\text { (Score) }\end{array}$ & $8 / 8$ & $100 \%$ & $2 / 8$ & $25 \%$ & $7 / 8$ & $88 \%$ \\
\hline Social cohesion (Score) & $4 / 4$ & $100 \%$ & $1 / 4$ & $25 \%$ & $2 / 4$ & $50 \%$ \\
\hline
\end{tabular}




\subsubsection{Creation and Distribution of Added Value}

This attribute has been evaluated using three indicators:

The first refers to the farmer revenue before taxes. In the local chains, higher prices per bottle (sold by the farmer) are balanced by both lower yields in grape production and the cost of working time needed for direct selling. The global bottled wine chain may perform better, as production cost is similar but selling is partially in the hands of retailers. Nevertheless, the variability between farms is higher, due to their international reputation. The global bulk chain has benefited from quite a high price range for PGI red wine recently, which creates better revenue for farmers as long as yields are around $90 \mathrm{hL} / \mathrm{ha}$, and the cost of grape production remains stable.

The second indicator concerns the "distribution of added value across the chain." To better assess the commercial margin captured by each actor of the chain, we have calculated three main expenses from primary and secondary data: (i) production cost of 75 centiliter of wine (including bottling and labelling costs in cases A and C); (ii) cost of logistics; and (iii) customs taxes. Figure 5 shows a breakdown of the end price of a 75 centiliter bottle, covering different expenses and areas of commercial margin determined by each actor in each case study. We have focused on two local chains, one involved in direct selling and the other selling through one local intermediary (wine shop, restaurant).

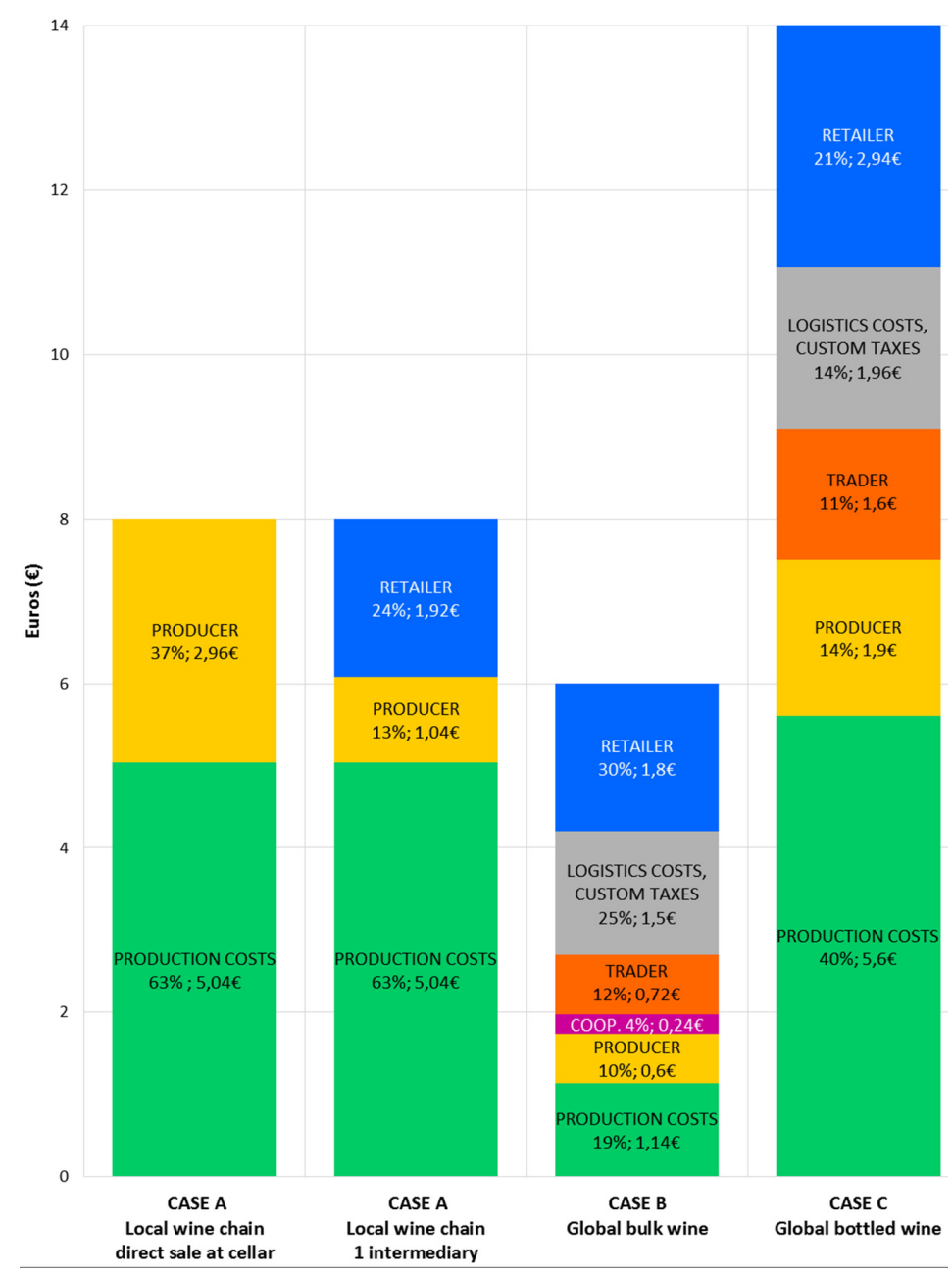

Figure 5. Breakdown of consumer price of bottle of still red wine in expenses and areas of commercial margin determined by each actor.

The highest production cost affects the local chains due to high labor cost, while in the global bulk wine chain, production cost per bottle is very low as suppliers benefit from an economy of scale. 
Nevertheless, the largest part of commercial margin to be kept by the producer can be observed in local direct selling. Producers and cooperatives in the global bulk chain secure their selling price with a PGI label, and it reached about 85€/hectoliter in the 2014-2015 campaign. In the global bottled chain, producers may realize a sensible commercial margin, depending on their reputation in the international market. However, we were not in a position to put forward performance scores using this indicator as no chain appeared to be skewed in favor of one particular actor.

The third indicator in "creation and distribution of added value" concerns the contribution to employment at the farm level. While case $\mathrm{A}$ is labor-intensive in managing production, processing and direct selling, case $B$ is highly mechanized: one person is expected to run 25 hectares alone. Case $C$ lies between the two, as sales require less working time.

\subsubsection{Connection}

In spite of reasonably similar scores in the three chains, the differences between the three cases are qualitatively important, as they demonstrate different forms of cooperation: mainly unformal exchanges between local peers in the case A, primarily aimed at developing wine tourism, landscaping and local cultural events; formal professional networks in case B, through involvement in cooperative boards and agricultural unions. In case $C$, producers are also involved in formal professional networks, but are more closely linked with AOP wine and marketing, including some prospective missions abroad.

\subsubsection{Biodiversity}

Both local and global bottled chains promote environmental approaches, including important practices regarding species conservation, according to experts. The local chain, which is less formally tied to the PDO system, shows more innovative practices than the global bottled chain, in areas of traditional variety conservation, agroecology and landscaping. In the PDO system, the possibility of valuing "old varieties" is more recent and is still restricted by the PDO code of practice. In the global bulk chain, "the ideal chain promotes 5-6 international varieties" (expert), even if cooperative members are increasingly adopting newer, more environmentally friendly guidelines. Nevertheless, the impact on biodiversity depends on the adoption of integrated, organic or biodynamic practices rather than on the type of chain, even if this adoption is influenced by market opportunities and by consumers and policy pressures, which operate in different combinations in each case.

\subsubsection{Resource Use}

PDO wines, mostly sold in cases A and C, receive very little, or no, irrigation. Instead, producers implement specific agricultural practices to conserve water and manage water stress, including mulching and canopy management. This is particularly true for case A, which is more oriented towards organic production. The global bulk wine chain, tied to the PGI label, is allowed to irrigate, but producers and cooperatives are involved in recent projects promoting better water use.

\subsubsection{Food Safety}

In local chains, official standards are obligatory ("wine of France" at a minimum) and controlled, but they have been partially substituted by direct interactions between producers and consumers. Chains targeting global markets must comply with more demanding official food safety standards. For global bottled markets, norms are often higher (for instance, traces of pesticides), and are in addition to PDO or organic requirements. Case $\mathrm{C}$ thus outperforms the others.

\subsubsection{Territoriality}

In the local chain, wine production and promotion rely on local resources and a strong connection with the terroir. The global bottled chain also uses territorial assets to develop the quality and reputation 
of the wine by exporting the territorial identity to international markets. Nevertheless, the score is lower since part of the added value is secured outside the territory. In the global bulk wine chain, the product is not greatly associated with the territory, as international brands promote varieties and generic names. Cooperatives, however, contribute to the value of some local resources and to keeping the first steps of the chain under farmer control.

Local chains rely on great investment in local and regional events, whether cultural or dedicated to wine, as well as in personal relations with consumers and tourists; "these events do not directly procure income, but they are long-term investments, allowing them greater visibility and to reach new clients" (expert). The global bottled chain is less involved in territorial social cohesion, as it is more oriented towards prestigious wine events abroad. In the global bulk wine chain, cooperatives favor social cohesion within the organization by allowing part-time, retired, and young workers to develop their activity within a group of members. Nevertheless, many experts noted a significant decrease in their contribution to social cohesion at a territorial level.

\subsection{Towards a Systematic Approach to Global Wine Chain Performance}

In this paper, we have focused on nine indicators to assess the contribution of three wine chains in diverse dimensions of sustainability. The results are thus partial, as the indicators have been selected more to illustrate our approach than to cover all the issues. Nevertheless, they allow an understanding of the specificities of the chains, as well as some interactions between items (e.g., farmer cooperation/territoriality), beyond the focus on local vs. global characteristics.

For the eight indicators (distribution of added value has not been included), no chain appears to be performing definitively better (see Figure 6); every chain gets some higher and lower results in comparison with the others, although the local chain does produce more positive scores. This result is important as it moves us beyond idealized visions of one type of chain or another, as well as provides an answer to critics, particularly of the local chain. We nevertheless have to keep in mind that this chain often combines PDO and organic production criteria, which contribute to its high score in specific dimensions.

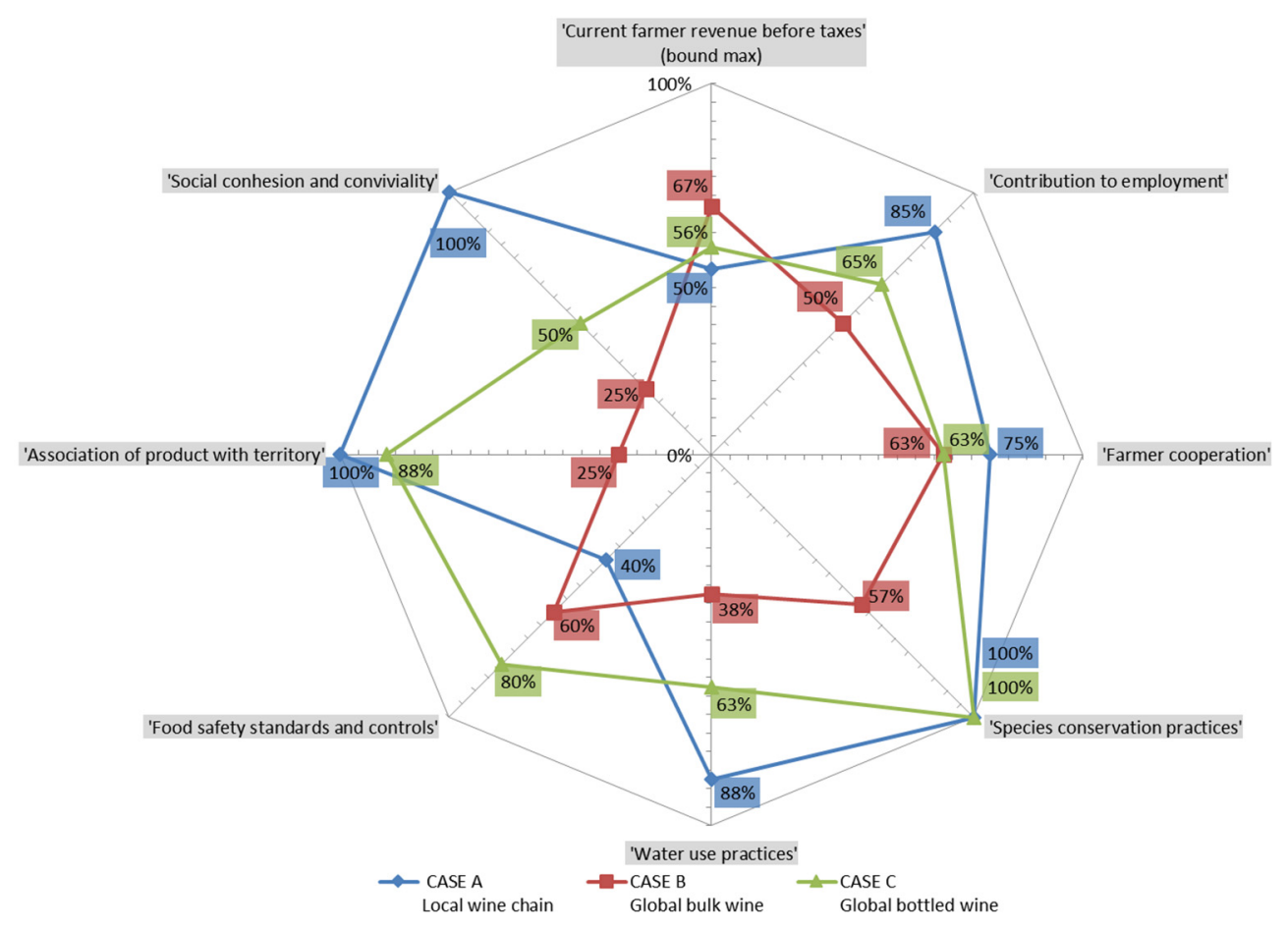

Figure 6. Radar plot of three wine chain performances. 


\section{Discussion}

In step one, we used an analytical approach to describe the local vs. global characteristics of three archetypal wine chains in Languedoc-Roussillon, including two extreme cases from local and global perspectives, respectively, and one intermediary case, which promotes local wines in global markets. However, the description of each chain highlighted local and global characteristics as assets, tools or constraints in strategies rather than as structural components of chains. In line with the GLAMUR project, we therefore developed a second interpretative and evaluative analytical step for the purpose of assessing the strategic components of the three chains from the point of view of sustainability. These strategic components mainly consist of practices, and these practices may be scored according to their contribution to sustainability in different domains, either directly (the practice improves the contribution) or indirectly (the practice produces/induces favorable conditions for a positive contribution). This shift from the first analytical approach to the assessment of practices in local or global wine chains has produced new insights, and has opened a debate between scientists and actors of the wine industry.

\subsection{Continuum of Situations Where Local and Global Practices Are Interlinked}

The five analytical dimensions of local vs. global allow for the identification of a wide range of concrete situations from "pure local" to "pure global" wine chains. From our starting categorization, the assessment in terms of sustainability suggests that the different types of chains are part of a continuum of situations where local and global practices are interlinked, even in the two extreme cases: in the most local chain (case A), some input or technologies (for instance, bottles and wine-making equipment) and a lot of professional information proceed from global flows; most importantly, "local buyers," including tourists, are strongly influenced by the global media that promotes the attractiveness of (some) local terroirs. In contrast, in the most global chain (case B), the wine cooperative remains a key actor in the bulk chain management, coordinating human and natural resources on a local scale, and giving quality/health and safety guarantees to traders and their supply chains. Our two-step approach has therefore led to a more detailed description of the three chains, in which many practices are dependent on both the local area and the global context. Moreover, thus far, grape production is not out-of-soil and needs land, locally adapted skills and the right to plant vines, and has to take into account local resources and environment, even with very intensive production models [44]. At the same time, in a globalized society, the purchase and consumption of wine-even in the most local face-to-face interactions-requires global/external judgments, standards and benchmarks [45].

\subsection{Development of Mixed Strategies}

This shared (to a greater or lesser degree) rooting in localness favors mixed strategies, particularly at a domain or cooperative level, which combine local chains with global chains, above and beyond local and global dimensions within the same chain. Indeed, many big wine cooperatives (case B) have built "tasting cellars" and "selling points," and have developed some niche markets with bottled wine, at least for their members, showing that "they can also produce quality and local wines." By contrast, private domains (case A or C) often sell a part of their production in bulk, if the vintage quality is lower, to market opportunities or to their storage management. The global bulk market thus plays a (generally marginal) role in the regulation of quality wine chains. However, above all, many domains and small cooperatives combine the export of their bottled wines (case $\mathrm{C}$ ) with direct selling and an implication in local projects (case A). At a farm or cooperative level, these mixed strategies are justified by the reduction of both local and global risks-complementarities in tangible and intangible investments in packaging or reputation, for example-or in access to a wider range of strategic information (such as in the evolution of consumers' preferences). In many renowned vineyards worldwide, the links between wine tourism and wine export have proved to be a successful synergy [13], as "nomad consumers" can be local (tourists or neighbors) or global (buyers of imported wine in supermarkets). The challenge, 
then, is to better understand what kind of local and global combination can be developed in specific situations, and how this combination can be sustainable for different types of actors, according to their values, capacities and constraints.

\subsection{Exploring the Impact of Local and Global Practices on Sustainability}

As in many sustainability assessments, we have found that no chain is revealed to perform better across the board. Many indicators demonstrate a better performance from the most local chains (case A), particularly in the social dimension of sustainability (social cohesion and conviviality). In this sense, although our research into the relational dimension in each chain is incomplete, paying closer attention to the concrete nature of relations from the viewpoint of economic sociology throws new light on food chains: on the one hand, our approach has found that the "social link" promoted in local chains is no longer ideological; on the other hand, our approach questions the quantitative scores of "social capital" which confuse different kinds of ties within food chains [46]. Nevertheless, the size of local markets is limited (about 15\% of Languedoc-Roussillon wine production), and criteria such as "net income" or "sanitary control" are better reached by the most global chain (case B), at least in the recent past. This calls for moving beyond the question of "are local chains better than global chains?" and developing a multidimensional, context-dependent and considered evaluation of "what kind of local, global or mixed practices can have a positive impact on the different dimensions of sustainability?" while being prepared for possible contradictions and trade-offs between these dimensions. The Languedoc-Roussillon region is facing both a high level of unemployment and a high rate of migration from northern and southern regions, which puts pressure on economic and natural resources such as local community budgets, water, land and biodiversity, as well as on social cohesion. Thinking about sustainability could initially lead to promoting the development of more local wine chains, but their direct impact on local economies could be lower than that of global wine chains, which are better able to exploit the opening of new external markets. Therefore, global chains (such as case B) could also be promoted, if we accept a trade-off with the social and environmental dimensions of sustainability by, for instance, including precision irrigation when water resources are available. These trade-offs between different dimensions of sustainability through the chains should evolve, and this would require periodic re-evaluation of local and global practices.

\subsection{Towards the Identification of Local and Global Solutions}

By focusing on practices using a "consequentialist approach," we have identified individual and collective solutions which would allow each chain to progress in different dimensions of sustainability. Local and global practices and their impact on sustainability depend on technical and organizational innovations that are partially specific to each chain. In the most local chains (case A), these solutions take place particularly through "local development projects" or "local community initiatives" that can enhance direct selling and sustainable wine tourism; in the most global chain (case B), sustainable solutions are driven by voluntary "corporate socially responsible" strategies or by quality supply chain management; in the intermediary case (case C), technical changes aimed at more sustainable wine chains, such as the reduction of pesticide use and GHG emissions, have been launched by PDO wine producer associations through new codes of practices [20]. The improvement in sustainable practices also relies on solutions that are not specific to either a local or global orientation in the chains, such as the adoption of organic certification, the evolution of the European wine policy, and the change in national social and environmental policies. Indeed, local and global characteristics of the wine chains are assets or targets that are partially orienting actors' strategies and innovations towards sustainability, following a co-evolution process with multilevel institutions and policies.

\subsection{Embeddedness of Actors' Practices, Reflexivity of Analysts}

From the viewpoint of economic sociology, we consider that local, global and mixed practices are not implemented by isolated, purely rational actors, but are socially constructed [39]. The implemented 
practices are not and cannot be the best from the standpoint of sustainability as they reflect the networks, values, and institutions in which they are embedded. In the most local chains, wine producers have, for the most part, informal ties with their colleagues and are greatly and personally invested in relations with consumers and are anchored in their local community. In the most global chains, grape producers are more involved in professional formal groups and networks, have little contact with consumers and clients and are less invested in their community. Their contrasting relational profile may be consistent with specific moral values or economic objectives [44]; we have also observed that in some cases it is not a choice, but it is inherited from their parents and difficult to change: in this sense, our research is also a way of creating some distance through the strategic vision of the relational dimension of markets and economic activities, developed in some economic sociology research from the English-speaking world [47]. In any case, it defines some opportunities for and constraints on action, and influences their judgement on "what suits" in specific contexts [34]. Scoring a high performance for "connection" and "social cohesion" in local chains is thus not sufficient, as it may be sustained rather than chosen, or may suit moral values while affecting wellbeing, as can be seen in the case of community-supported agriculture schemes where producers who value social links with consumers seem to be self-exploiting [48].

From the broader perspective of economic sociology, the two steps of our approach-analytical and consequentialist, respectively - may thus be completed by an analysis of cultural, institutional and relational embeddedness of practices in local and global wine chains [49]. From this contextualizing viewpoint, the performance assessment of practices may consider (i) actors' projects, resources, networks and capacities at various stages in the chains; and (ii) new indicators of wellbeing and development [41] driven by a deliberative regime and supported by public policies to both assess and support the contribution of the chains to sustainability.

\section{Conclusions}

In this article we first tried to objectivize which aspects of wine are local, and which are global by referring to five dimensions: the geographical distance between consumption and production, the number of intermediaries along the value chain, the nature of incorporated resources, product identity, and the leading actors as regards governance. Using an analysis of three archetypal wine chains in the south of France, we completed this first analytical approach using a more interpretative and evaluative approach of wine chain sustainability, by combining the GLAMUR approach with an economic sociology perspective. Qualitative indicators of sustainability were scored and benchmarked by experts to compare local $v s$. global practices in the three wine chains, highlighting "new indicators of wealth", notably in the social dimension. This consequentialist approach has revealed that: (i) in all concrete situations local and global practices are interlinked; (ii) many actors are taking advantage of their involvement in global and local wine chains; (iii) the most local chain performs better than the global one, as far as social and environmental dimensions of sustainability are concerned, but the global chain contributes greatly to economic development; (iv) the implementation of solutions for more sustainable practices is partially specific to either a local or a global orientation in the chains; (v) in the end, the sustainability assessment of local and global practices in the wine chains depends on the values, capacities and networks built by the actors, and calls for further research into food chain performances by taking their contextualization more into consideration, with the help of economic sociology. However, within this assessment process, the analysts themselves are not outside the situation and their influence on the whole process of evaluation has also to be considered. Our two-step attempt to objectivize food chains as social constructions may thus be pursued with a contextualizing and reflexive third step.

Acknowledgments: The research which led to these results received funding from the European Union's Seventh Programme (GLAMUR project). We also acknowledge all the participants of the GLAMUR project for the fruitful scientific exchanges that have directly contributed to this article, and the stakeholders of different wine chains (specially the wine producers) who have been involved in the different steps of this participatory work. We thank 
the two anonymous reviewers for their comments on a first version of this article, and Laura Amalir for her careful English editing of our paper.

Author Contributions: Jean-Marc Touzard and Yuna Chiffoleau designed the research in agreement with the GLAMUR research team; Camille Maffezzoli and Jean-Marc Touzard collected the data, organized the focus group and structured the results of the three wine chains; Jean-Marc Touzard, Yuna Chiffoleau and Camille Maffezzoli have equally contributed to the writing of the article.

Conflicts of Interest: The authors declare no conflict of interest.

\section{Appendix}

Table A1. Measurement and benchmark for the indicators of the 6 attributes selected in the wine example.

\begin{tabular}{|c|c|c|c|}
\hline Attribute/Indicator & Measurement (Unit) & Benchmark & $\begin{array}{l}\text { Benchmark } \\
\text { Ranking }\end{array}$ \\
\hline \multicolumn{4}{|c|}{ Creation and distribution of added value } \\
\hline $\begin{array}{l}\text { Farmer revenue } \\
\text { before taxes }\end{array}$ & $\begin{array}{c}\text { Revenue before taxes per } \\
\text { farmer in wine production } \\
\text { per non-salaried } \\
\text { worker,(Euro per Annual } \\
\text { Work Unit, } € / \text { AWU) }\end{array}$ & $\begin{array}{l}\text { Average revenue (2011-2013) for wine production in } \\
\text { Languedoc }=17,900 € / \text { AWU (Agreste, 2014) }\end{array}$ & $\begin{array}{l}\text { High: } 35,800 \\
\text { Middle: } 17,900 \\
\text { Low: } 0\end{array}$ \\
\hline $\begin{array}{l}\text { Distribution of } \\
\text { added value } \\
\text { along the chain }\end{array}$ & $\begin{array}{l}\text { Breakdown of the bottle } \\
\text { consumer price in costs, } \\
\text { taxes and commercial } \\
\text { margins (percentage of the } \\
\text { selling price, } \% \text { ) }\end{array}$ & $\begin{array}{l}\text { Performance is interpreted through, (1) a comparison } \\
\text { within the chain (between actors) and ( } 2 \text { ) a } \\
\text { comparison between chains (cases A, B and C) }\end{array}$ & $\begin{array}{c}\text { Contextual } \\
\text { analysis (takes } \\
\text { into account the } \\
\text { governance of } \\
\text { the chain) }\end{array}$ \\
\hline $\begin{array}{c}\text { Contribution to } \\
\text { employment }\end{array}$ & $\begin{array}{l}\text { Total number of hours } \\
\text { worked, at farm level, for } \\
\text { wine production and } \\
\text { selling (Full Time } \\
\text { Equivalent per unit of } \\
\text { land, FTE/ha) }\end{array}$ & $\begin{array}{l}\text { Reference: } 1 \mathrm{FTE}=229 \text { working days / year, } 1607 \mathrm{~h} \text { in } \\
\text { France (Insee) } \\
\text { Average regional rate for wine } \\
\text { production }=0.1 \mathrm{FTE} / \text { ha (Agreste) }\end{array}$ & $\begin{array}{l}\text { High: }>0.2 \\
\text { Middle: } 0.1 \\
\text { Low: } 0\end{array}$ \\
\hline \multicolumn{4}{|c|}{ Connection } \\
\hline $\begin{array}{l}\text { Farmer } \\
\text { cooperation }\end{array}$ & $\begin{array}{l}\text { Score the forms of } \\
\text { cooperation among wine } \\
\text { producers ( } 1 \text { point per } \\
\text { criterion validated, total of } \\
8 \text { points) }\end{array}$ & $\begin{array}{l}\text { 1. Count up the active participation in: } \\
\text { 1.1. Local winemaker association/1.2. Regional } \\
\text { farmers' unions/1.3. Wine cooperative/1.4. } \\
\text { Cooperative for the use of agricultural } \\
\text { equipment (CUMA) } \\
\text { 2. Count up the existence of mutual support } \\
\text { among farmers: } \\
\text { 2.1. Exchange of advice/2.2. Share equipment/2.3. } \\
\text { Share services, human resource/2.4. Collaborate in } \\
\text { collective projects/wine tourism }\end{array}$ & $\begin{array}{l}\text { High: } 8 / 8 \\
\text { Middle: } 4 / 8 \\
\text { Low: } 0 / 8\end{array}$ \\
\hline \multicolumn{4}{|c|}{ Biodiversity } \\
\hline $\begin{array}{l}\text { Species } \\
\text { conservation } \\
\text { practices }\end{array}$ & $\begin{array}{l}\text { Score the practices related } \\
\text { to management of } \\
\text { biodiversity at farm level } \\
\text { ( } 1 \text { point per criterion } \\
\text { validated, count up the } \\
\text { criteria, total of } 7 \text { points) }\end{array}$ & $\begin{array}{l}\text { 1. Diversity of vine varieties at farm level: } \\
\text { 1.1. If vine varieties }>5 / 1.2 \text {. If traditional vine } \\
\text { varieties (Mourvèdre, Carignan, Cinsault ... ) } \geqslant 2 \\
\text { 2. Uncultivated biodiversity: landscape, flora and } \\
\text { fauna protection } \\
\text { 2.1. Presence of an ecological zone, forest or } \\
\text { agro-forestry area/2.2. Maintaining an inter-row and } \\
\text { row grass cover } / 2.3 \text {. Preserving scarps, bushes, } \\
\text { hedges and the uncultivated edges } \\
\text { 3. Integration of agro-ecological practices for } \\
\text { pest control: } \\
\text { 3.1. Installation of pest traps in the fields } / 3.2 \text {. } \\
\text { Fostering and introducing natural auxiliaries }\end{array}$ & $\begin{array}{l}\text { High: } 6 / 6 \\
\text { Middle: } 3 / 6 \\
\text { Low: } 0 / 6\end{array}$ \\
\hline
\end{tabular}


Table A1. Cont.

\begin{tabular}{|c|c|c|c|}
\hline Attribute/Indicator & Measurement (Unit) & Benchmark & $\begin{array}{l}\text { Benchmark } \\
\text { Ranking }\end{array}$ \\
\hline \multicolumn{4}{|c|}{ Resource use } \\
\hline $\begin{array}{l}\text { Water Use } \\
\text { Practices }\end{array}$ & $\begin{array}{l}\text { Score the practices related } \\
\text { to water use at the level of } \\
\text { vineyard management. ( } 0 \text {, } \\
1 \text { or } 2 \text { points per criterion } \\
\text { validated, total of } 8 \text { points) }\end{array}$ & $\begin{array}{l}\text { 1. Select the irrigation strategy for grape production: } \\
\text { 1.1. No irrigation }(2 \text { points }) / 1.2 \text {. Irrigation } \\
\text { limited/controlled in time and quantity ( } 1 \text { point }) / 1.3 \text {. } \\
\text { Intensive irrigation, large authorization period } \\
(0 \text { point) } \\
\text { 2. Select the technology and equipment used for } \\
\text { irrigation: } \\
\text { 2.1. Only rainfall and runoff water ( } 2 \text { points) } / 2.2 \text {. } \\
\text { Localized irrigation (drip irrigation) or sprinkling } \\
\text { equipment }(1 \text { point }) / 2.3 \text {. Overhead irrigation system } \\
\text { or furrow irrigation }(0 \text { point) } \\
\text { 3. Count up water preservation practices: } \\
\text { 3.1. Mulching ( } 2 \text { points }) / 3.2 \text {. Inter-row cover crops } \\
(1 \text { point }) / 3.3 \text {. Tighter crop hoeing ( } 1 \text { point) }\end{array}$ & $\begin{array}{c}\text { High: } 8 / 8 \\
\text { Middle: } 4 / 8 \\
\text { Low: } 0 / 8\end{array}$ \\
\hline \multicolumn{4}{|c|}{ Food safety } \\
\hline $\begin{array}{l}\text { Food Safety } \\
\text { Standards and } \\
\text { controls }\end{array}$ & $\begin{array}{l}\text { Score the practices linked } \\
\text { with management of food } \\
\text { security at the level of the } \\
\text { chain (1 point per criterion } \\
\text { validated, count up the } \\
\text { criteria, total of } 5 \text { points) }\end{array}$ & $\begin{array}{l}\text { 1. Direct relations between producer and consumer } \\
\text { 2. Control and monitoring by third-party organisms } \\
\text { 3. Implementation of management system along } \\
\text { the chain: } \\
\text { 3.1. Risks analysis HACCP/3.2. For quality ISO } \\
\text { 9001/3.3. For food safety ISO } 22000\end{array}$ & $\begin{array}{c}\text { High: } 5 / 5 \\
\text { Middle: } 2.5 / 5 \\
\text { Low: } 0 / 5\end{array}$ \\
\hline \multicolumn{4}{|c|}{ Territoriality } \\
\hline $\begin{array}{l}\text { Association of } \\
\text { product with } \\
\text { territory }\end{array}$ & $\begin{array}{l}\text { Score the practices } \\
\text { contributing to maintain } \\
\text { the environmental, } \\
\text { economic dynamics and } \\
\text { specificities of the wine } \\
\text { production areas. ( } 1 \text { or } \\
2 \text { points per criterion } \\
\text { validated, count up the } \\
\text { criteria, total of } 8 \text { points) }\end{array}$ & $\begin{array}{l}\text { 1. Enhancing landscape and terroir: } \\
\text { 1.1. Maintenance of agro-ecological infrastructures in } \\
\text { the vineyard (low walls, vineyard shelters, ruins, } \\
\text { veteran trees, centenarian vines, etc.) One or more } \\
\text { practices }(1 \text { point }) / 1.2 \text {. Preservation and keeping the } \\
\text { vineyard visible from the outside. One or more } \\
\text { practices }(1 \text { point }) / 1.3 \text {. Creation of discovery } / \text { hiking } \\
\text { areas in the vineyard. ( } 1 \text { point) } \\
\text { 2. Contribution to territorial economic development: } \\
\text { Percentage of commercial margin }(\mathrm{CM}) \text { remaining on } \\
\text { the territory } \\
\text { 2.1. If commercial margin }<50 \%(0 \text { point }) / 2.2 \text {. If } \\
\text { commercial margin } 50 \% \leqslant C M \leqslant 75 \%(1 \text { point }) / 2.3 \text {. } \\
\text { If commercial margin }>75 \%(2 \text { points) } \\
3 \text {. Average number of full-time jobs (FT) at } \\
\text { farm level: } \\
3.1 \text { If FT }=0 \text { ( } 0 \text { point }) / 3.2 \text {. If } 1 \leqslant \mathrm{FT} \leqslant 2 \\
(1 \text { point }) / 3.3 \text {. If FT }>2(2 \text { points) } \\
4 \text {. Use of knowledge and know-how valuing } \\
\text { the "terroir": } \\
4.1 \text { Vineyard management under PDO label } \\
(1 \text { point }) / 4.2 \text {. Practices respecting PDO criteria } \\
\text { without the label ( } 1 \text { point) }\end{array}$ & $\begin{array}{c}\text { High: } 8 / 8 \\
\text { Middle: } 4 / 8 \\
\text { Low: } 0 / 8\end{array}$ \\
\hline $\begin{array}{l}\text { Social cohesion } \\
\text { and conviviality }\end{array}$ & $\begin{array}{l}\text { Score the practices } \\
\text { contributing to maintain } \\
\text { the social and ethical } \\
\text { dynamics in the wine } \\
\text { production areas (1 point } \\
\text { per practice validated, } \\
\text { count up the criteria, total } \\
\text { of } 4 \text { points) }\end{array}$ & $\begin{array}{l}\text { Participation of wine actors to territorial } \\
\text { initiatives/events: } \\
\text { 1.1. Local/regional wine fairs } / 1.2 \text {. Local/regional } \\
\text { cultural events/1.3. Wine tourism on farm, direct } \\
\text { exchanges producers/consumers } / 1.4 \text {. Direct sale } \\
\text { at cellar }\end{array}$ & $\begin{array}{c}\text { High: } 4 / 4 \\
\text { Middle: } 2 / 4 \\
\text { Low: } 0 / 4\end{array}$ \\
\hline
\end{tabular}




\section{References}

1. Hinrichs, C. Embeddedness and local food systems: Notes on two types of direct agricultural market. J. Rural Stud. 2000, 16, 295-303. [CrossRef]

2. Goodman, D. The quality "turn" and alternative food practices: Reflections and agenda. J. Rural Stud. 2003, 19, 1-7. [CrossRef]

3. Friedman, H. Scaling up: Bringing public institutions and food service corporations into the project for a local, sustainable food system in Ontario. Agric. Hum. Values. 2007, 24, 389-398. [CrossRef]

4. Morgan, K.; Marsden, T.; Murdoch, J. Worlds of Food: Place, Power, and Provenance in the Food Chain; Oxford University Press: Oxford, UK, 2008.

5. Brunori, G. Local food and alternative food networks: A communication perspective. Available online: https:/ / aof.revues.org/430 (accessed on 17 April 2016).

6. Dion, R. Histoire de la Vigne et du Vin en France, des Origines au XIXe Siècle; Flamarion: Paris, France, 1959.

7. Karpik, L. Valuing the Unique: The Economics of Singularities; Princeton University Press: Princeton, NJ, USA, 2010.

8. Bourdieu, P. La Distinction. Critique Sociale du Jugement; Editions de Minuit: Paris, France, 1979.

9. Schirmer, R. Le regard des géographes francais sur la vigne et le vin. Ann. Géogr. 2000, 109, 614-615.

10. Pitte, J.-R. Le Bon Vin, Entre Terroir, Savoir-Faire et Savoir-Boire; Edition du CNRS: Paris, France, 2010.

11. Auriac, F. Système Economique et Espace; Economica: Paris, France, 1983.

12. Unwin, T. Wine and the Vine: An Historical Geography of Viticulture and the Wine Trade; Routledge: London, UK, 1996.

13. Touzard, J.-M.; Vandecandelaere, E. Création de ressources territoriales et construction de la qualité. Les routes des vins. In Proximités et Changements Socio-Economiques dans les Mondes Ruraux; Torre, A., Fillippi, M., Eds.; Inra Editions: Paris, France, 2005; pp. 59-72.

14. Peris-Ortiz, M.; Del Río Rama, M.; Rueda-Armengot, C. Wine and Tourism. A Strategic Segment for Sustainable Economic Development; Springer: Berlin, Germany, 2016.

15. Chiffoleau, Y.; Laporte, C. Price formation: The case of Burgundy wine. Rev. Fr. Sociol. 2006, 47, $157-182$. [CrossRef]

16. Garcia-Parpet, M.-F. Le Marché de L'excellence: Les Grands Crus à L'épreuve de la Mondialisation; Editions du Seuil: Paris, France, 2011.

17. Dedeire, M.; Giraudel, J.-L. La distance cognitive avec le territoire d'origine du produit alimentaire. Econ. Rural. 2008, 301, 36-54. [CrossRef]

18. Krzywoszynska, A. Wine is not Coca-Cola: Marketization and taste in alternative food networks. Agric. Hum. Values. 2015, 32, 491-503. [CrossRef]

19. Carter, B. Trust, regulation and the creation of high value-added markets: European wine markets in comparative perspective. In Trust in Regulatory Regimes; Six, F., Verhoest, K., Eds.; Edward Elgar: Cheltenham, UK, 2016.

20. Belleti, A.; Marescotti, A.; Touzard, J.-M. Geographical Indications, Public Goods and Sustainable Development: The roles of actors' strategies and public policies. World Dev. 2015. [CrossRef]

21. Vaudour, E. The Quality of Grapes and Wine in Relation to Geography: Notions of Terroir at Various Scales. J. Wine Res. 2002, 13, 117-141. [CrossRef]

22. Delfosse, C. La Mode du Terroir et les Produits Alimentaires; Les Indes Savantes: Paris, France, 2011. (In French)

23. Bérard, L.; Marchenay, P. Les Produits de Terroir: Entre Culture et Règlements; CNRS Éditions: Paris, France, 2004.

24. Barham, E.; Sylvander, B. Labels of Origin for Food: Local Development, Global Recognition; CAB International: Wallingford, UK, 2011.

25. Barham, E. Translating terroir: The global challenge of French AOC labeling. J. Rural Stud. 2003, 19, 127-138. [CrossRef]

26. Duncan, A.; Greenaway, D. The Economics of Wine. Econ. J. 2008, 118, 137-141. [CrossRef]

27. Giraud-Heraud, E.; Pichery, M.-C. Wine Economics: Quantitative Studies and Empirical Applications; Palgrave Macmillan: London, UK, 2013. 
28. Chiffoleau, Y.; Laporte, J.-P.; Touzard, J.-M. La construction des marchés et signes de qualité à l'échelle régionale: L'exemple des Vins en Languedoc-Roussillon. In Produits Agricoles et Alimentaires D'origine: Enjeux et Acquis Scientifiques; Sylvander, B., Casabianca, F., Roncin, F., Eds.; Inra Editions: Paris, France, 2008; pp. 130-137. (In French)

29. Anderson, K.; Norman, D.; Wittwer, G. Globalisation of the World's Wine Markets. World Econ. 2003, 26, 659-687. [CrossRef]

30. Chambolle, C.; Saulpic, O. Growers vs. merchants bargaining on the price of champagne grapes. J. Wine Econ. 2006, 1, 95-113. [CrossRef]

31. Rebelo, J.; Caldas, J. The Douro wine region: A cluster approach. J. Wine Res. 2013, 24, 19-37. [CrossRef]

32. Ponte, S.; Ewert, J. Which way is "up" in upgrading? Trajectories of change in the value chain for South African wine. World Dev. 2009, 37, 1637-1650. [CrossRef]

33. Codron, J.M.; Montaigne, E.; Rousset, S. Quality management and contractual incompleteness: Grape procurement for high-end wines in Argentina. J. Chain Netw. Sci. 2013, 10, 11-35. [CrossRef]

34. Favereau, O.; Lazega, E. Conventions and Structures in Economic Organization; Edward Elgar: Cheltenham, UK, 2003.

35. Touzard, J.-M.; Chiffoleau, Y.; Dreyfus, F. Analyser L'innovation dans un système agroalimentaire localisé: Approche interdisciplinaire en Languedoc. Cah. Agric. 2008, 17, 526-531. (In French).

36. Gereffi, G.; Humphrey, J.; Sturgeon, T. The governance of global value chains. Rev. Int. Polit. Econ. 2005, 12, 78-104. [CrossRef]

37. The Food and Agriculture Organization of the United Nations (FAO). Sustainability Assessment of Food and Agriculture Systems; FAO: Rome, Italy, 2013.

38. Swedberg, R. Principles of Economic Sociology; Princeton University Press: Princeton, NJ, USA, 2007.

39. Granovetter, M.S. Economic action and social structure. The problem of embeddedness. Am. J. Sociol. 1985, 91, 481-510. [CrossRef]

40. Steiner, P. La Sociologie Économique; Editions La Découverte: Paris, France, 1999. (In French)

41. Chiffoleau, Y. From politics to co-operation: The dynamics of embeddedness in alternative food supply chains. Sociol. Rural. 2009, 49, 218-235. [CrossRef]

42. Gadrey, J.; Jany-Catrice, F. Les Nouveaux Indicateurs de Richesse; Editions La Découverte: Paris, France, 2006. (In French)

43. Jouan, J. Les AOC Viticoles Face au Changement Climatique: Exploration des Voies D'adaptation par la Prospective et L'analyse Economique; Mémoire de fin D'étude D'ingénieur; AgroCampus Ouest: Rennes, France, 2014. (In French)

44. Chiffoleau, Y.; Touzard, J.-M. Understanding local agri-food systems through advice network analysis. Agric. Hum. Values 2014, 31, 19-32. [CrossRef]

45. Teil, G. De la Coupe aux Lèvres-Pratiques de la Perception et Mise en Marché de Vins de Qualité; Éditions Octarès: Toulouse, France, 2004. (In French)

46. Trienekens, H.H.; Omta, S.W.F. Paradoxes in Food Chains and Networks; Wageningen Academic Publishers: Wageningen, The Netherlands, 2002.

47. Burt, R.S. Structural Holes: The Social Structure of Competition; Harvard University Press: Cambridge, MA, USA, 1995.

48. Galt, R. The Moral Economy is a Double-edged Sword: Explaining Farmers' Earnings and Self- exploitation in Community-Supported Agriculture. Econ. Geogr. 2013, 89, 341-365. [CrossRef]

49. White, H.C. Markets from Networks; Princeton University Press: Princeton, NJ, USA, 2002.

(c) 2016 by the authors; licensee MDPI, Basel, Switzerland. This article is an open access article distributed under the terms and conditions of the Creative Commons Attribution (CC-BY) license (http://creativecommons.org/licenses/by/4.0/). 